\title{
Modeling of Coal Deposition Using the Resistivity Method with Wenner Configuration in the Bentarsari Basin Area, District of Salem, Brebes Regency, Central Java
}

\author{
Putri Suci Ramdani and Sehah* \\ Department of Physics, Faculty of Mathematics and Natural Sciences, Jenderal Soedirman University \\ Street of Dr. Suparno No.61, Purwokerto Central Java Indonesia
}

\begin{abstract}
Research to model coal deposits in the Bentarsari Basin area of Salem District in Brebes Regency has been done using the geoelectric-resistivity method with Wenner configuration. Resistivity data acquisition is carried out on five tracks, with each track has a length of $200 \mathrm{~m}$. The least squares inversion method is applied to obtain a 2D-resistivity section model. Furthermore, the 2D-resistivity section model data for each line is combined into a 3D model to determine the coal deposit model in the area. The results of the interpretation indicate that the subsurface structure of the area consists of clay, sandy clay, coal, and sandstone; where the type of coal is lignite. This coal deposit has resistivity values with interval of 86.1-219.0 $\Omega \mathrm{m}$, which is distributed evenly with depth of 0.0-26.5 m, where the southern part of the all track has a higher potential. This research can be followed up with log drill testing to determine the actual subsurface layer, so that it can be utilized as a very economical alternative energy.
\end{abstract}

Keywords: Bentarsari Basin; coal deposit; geoelectric method; Wenner configuration.

*Corresponding author: sehah@unsoed.ac.id

Article history: Received 5 March 2020, Accepted 16 July 2020, Published January 2021.

http://dx.doi.org/10.12962/j24604682.v17i1.6897

2460-4682 @DDepartemen Fisika, FSAD-ITS

\section{INTRODUCTION}

Along with the rapid development of technology, energy needs are also increasing from time to time. The national energy needs will not sufficiently met if only relying on the remaining energy sources of oil and natural gas. Therefore, alternative energy is needed to help fulfilling those energy needs; and one of them is coal. Coal is a type of combustible rock, formed from the remnants of ancient plants that are generally trapped in a basin through physical and chemical processes in nature since deposition [1], resulting in enrichment in its carbon content. Coal seams in nature are generally brown to black and occur in sedimentary geological layers [1]. Naturally, the process of forming coal deposits is divided into two types, namely peat, and coalification. In the geochemical process, plant trapped in rocks undergo metamorphosis into peat, and after it undergoes physical processes such as stockpiling so that it becomes young coal (for example lignite). The longer the young coal turns into old coal, which is sub-bituminous to bituminous [2]. Bituminous contains 68$86 \%$ carbon $(\mathrm{C})$ with a moisture content of $8-10 \%$ of its mass, while sub-bituminous contains a little carbon and a lot of water, making it a less efficient heat source compared to bituminous [2].

Indonesia's coal reserves are quite large, around 36 billion tons spread across several islands, such as Sumatra, Kalimantan, Java, Sulawesi, and Papua [1]. One area in Java that has coal reserves is the Bentarsari Basin, located in Salem Dis- trict, Brebes Regency, Central Java. Research to determine the presence of coal in the area has been carried out using the satellite imagery gravity method. The results show that coal is embedded in sandstone with a density of $2.17 \mathrm{~g} / \mathrm{cm}^{3}$ which is located in the Kaliglagah Formation as a solid bitumen carrier rock at a depth of 300-400 m [3]. Besides, research with magnetic methods has also been carried out in the area which resulted in the estimated content of coal bitumen inserts with a magnetic susceptibility value of $0.0008 \mathrm{cgs}$ units at depths of 104.478-505.970 m [4].

The gravity method that relies on satellite data still contains doubts, because the results of the interpretation are not single (non-unique) so that there are different interpretation results. To overcome this, a study was conducted using another method, namely the magnetic method. The results of the study using magnetic methods also have the disadvantage of not being able to know specific rock layers in the horizontal direction so that coal outcrops on the surface are not detected so that further methods with better accuracy are needed to determine the specific structure of the coal seams on the surface. The advanced method used is the Wenner configuration resistivity geoelectric method to find out more specific surface layer structures in the horizontal and vertical directions $[5,6]$. The resistivity geoelectric method is used to study or understand the structure of the subsurface of the earth through measurements of electrical quantities on the surface. Since coal is a layer of sedimentary rocks which tends to be homogeneous, the Wenner configuration resistivity geoelectric 


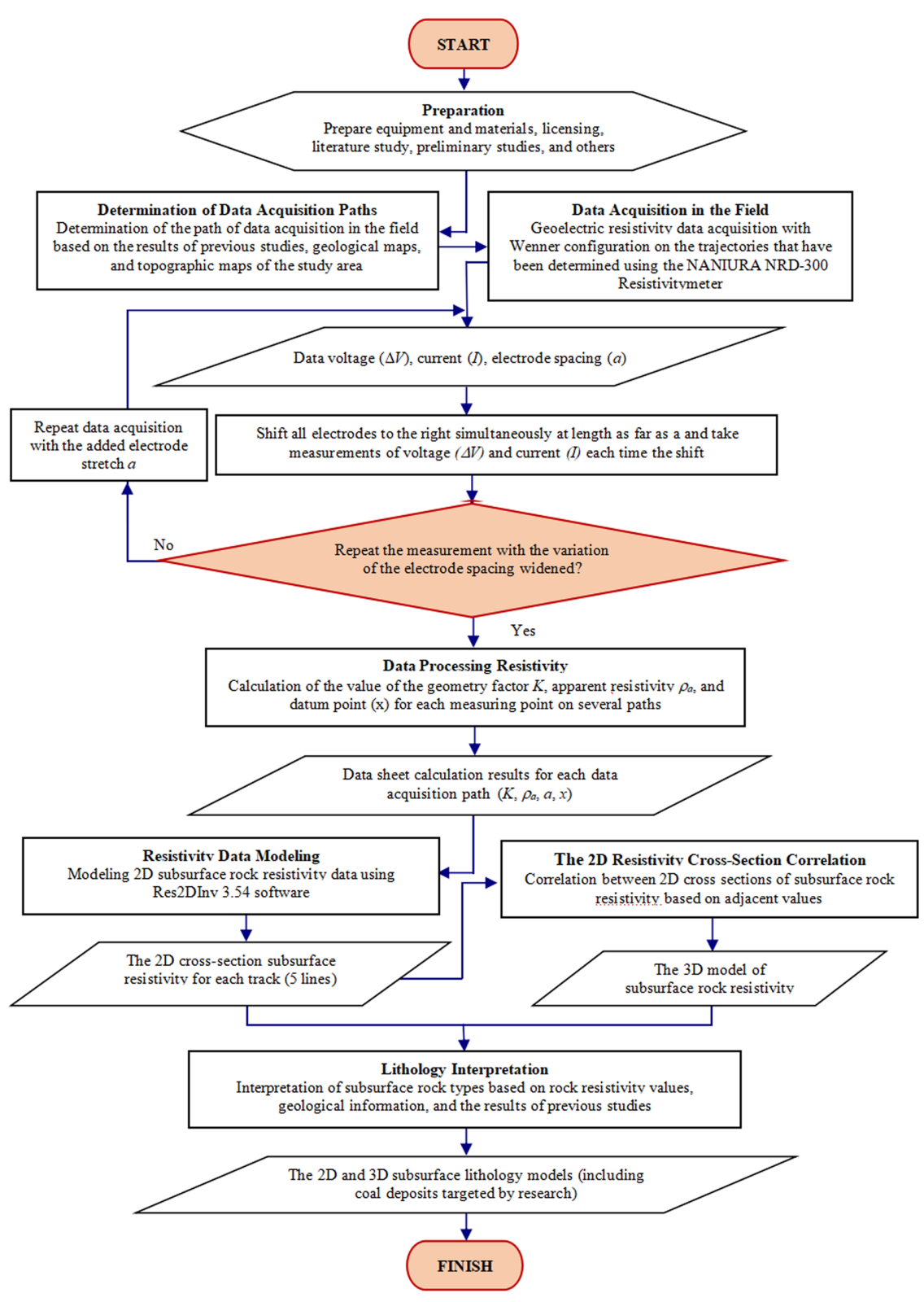

FIG. 1: Flowchart of research using the resistivity geoelectric method with the Wenner configuration [10].

method is very suitable, because this method displays information on the change in resistivity value variation in the horizontal and vertical directions [6]. Also, the Wenner configuration has advantages in reading accuracy because it has a value of eccentricity that is not too large [7].

\section{RESEARCH METHOD}

The resistivity geoelectric method is a geophysical method that utilizes the resistivity properties of rocks in the earth to study subsurface conditions. The principle of resistivity geoelectric method is to inject electric current into the earth through two electrodes $C_{1}$ and $C_{2}$ currents that move through the subsurface medium, then the potential difference that occurs due to differences in electric polarization is measured through two electrodes potential $\mathrm{P}_{1}$ and $\mathrm{P}_{2}$. After the current and potential difference data are obtained, the apparent subsurface resistivity value can be calculated using the equation:

$$
\rho_{a}=K \frac{\Delta V}{I}
$$

where $\rho_{a}$ is apparent resistivity, $\mathrm{V}$ is the measured potential difference, $\mathrm{I}$ is the injected current, and $\mathrm{K}$ is the geometry factor whose value is under the configuration applied [8]. The complete flow diagram of this research can be seen in Fig. 1. Fig. 2 shows the configuration of the Wenner configuration with two current electrodes mounted on the outside of the po- 


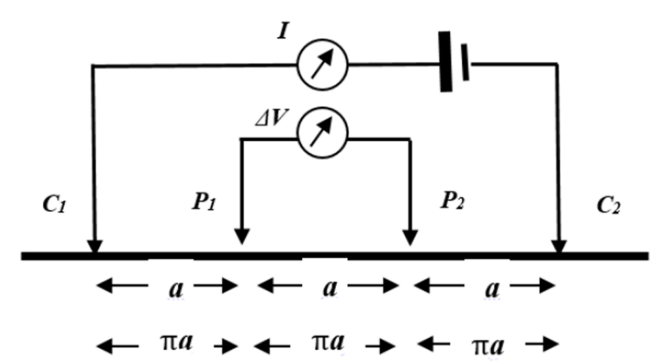

FIG. 2: Current and potential electrode arrangement for the acquisition of resistivity geoelectric data using the Wenner configuration [9].

tential electrode with the distance between the electrodes of [8]. In the Wenner configuration, the distance between the current electrode and potential electrode is the same, so the value of $\mathrm{C}_{1} \mathrm{P}_{1}=\mathrm{P}_{1} \mathrm{P}_{2}=\mathrm{P}_{2} \mathrm{C}_{2}=\mathrm{a}$. Geometry factors for the Wenner configuration are [8]:

$$
K=2 \pi a
$$

The apparent resistivity for the Wenner configuration can be calculated from equation (1) by entering a value of $\mathrm{K}=2 \pi$ a, so the apparent resistivity can be expressed as:

$$
\rho_{a}=2 \pi a \frac{\Delta V}{I}
$$

Exploration research of coal deposits using the resistivity geoelectric method was carried out in the Bentarsari Basin area, Salem District, Brebes Regency as shown in Fig. 3. The equipment used at the time of data acquisition is Naniura NRD 300 Resistivitymeter, current and potential electrodes, batteries, meters, cable rollers, connecting cables, hammer, Global Positioning System (GPS), Handy Talkie (HT), laptops, stationery, research data worksheets, and Majenang geology maps. The equipment used to process data is a laptop equipped with various application programs such as Microsoft Excel, Notepad 10, Res2Dinv 3.54, and Voxler 4. The number of trajectories for resistivity data acquisition with Wenner configuration is 5 tracks; with each track having a length of $200 \mathrm{~m}$. The tracks are Line-01, Line-02, Line-03, Line-04, and Line-05. The five tracks are located in the geographical position listed in Table I.

In the data acquisition stage, the first thing to do is to connect the current electrodes $\left(\mathrm{C}_{1}\right.$ and $\left.\mathrm{C}_{2}\right)$ and potential electrodes $\left(\mathrm{P}_{1}\right.$ and $\left.\mathrm{P}_{2}\right)$ to the resistivity meter. The spacing between the electrodes is regulated and starts from a, $2 \mathrm{a}, 3 \mathrm{a}$, and so on to produce data acquisition level $\mathrm{n}=1,2,3$, and so on as shown in Fig. 4. Data acquisition is done by injecting currents to the earth surface through current electrodes $\left(\mathrm{C}_{1}\right.$ and $\left.\mathrm{C}_{2}\right)$. The injected current spreads evenly throughout the rock in the subsurface, then the potential difference arising is received by the potential electrodes $\left(\mathrm{P}_{1}\right.$ and $\left.\mathrm{P}_{2}\right)$. Data acquisition can be repeated by shifting the electrodes as far as a and widening the electrode stretch range in the order of the spacing between the electrodes. Data obtained from the data acquisition results are the potential difference $(\Delta \mathrm{V})$, the current strength (I), and the distance between the electrodes (a) [10].

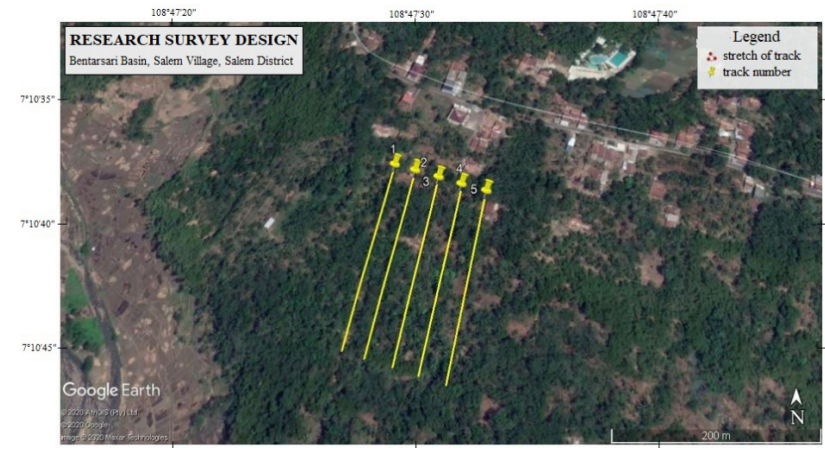

FIG. 3: Research area located in Salem District Brebes Regency (earth.google.com).

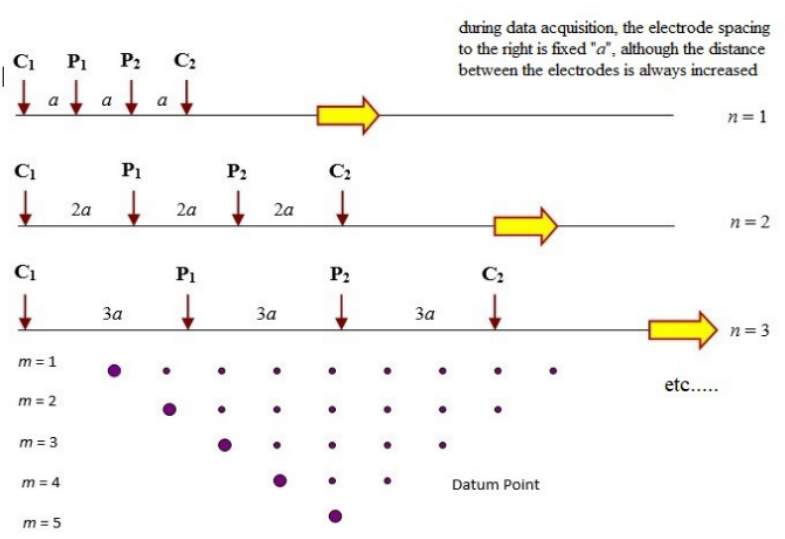

FIG. 4: The design of data acquisition laterally mapping using the Wenner configuration [9].

Based on the data of potential difference $(\Delta V)$, current (I), and spacing between electrodes (a), then the geometry factor value $(\mathrm{K})$ for the Wenner configuration and apparent resistivity $\left(\rho_{a}\right)$ can be calculated. The apparent resistivity data obtained is then modeled into a $2 \mathrm{D}$ resistivity cross-section model. Modeling is done using the least-squares inversion linear method by matching the model data and observational data [11]. The least-squares inversion technique is one technique that is often used to obtain the values of parameters in linear regression modeling. In general, the least square equation is:

$$
\begin{aligned}
\left(J^{T} J+\mu F\right) d & =J_{T} g-\mu F r \\
F & =f_{x} f_{x}^{T}+f_{z} f_{z}^{T}
\end{aligned}
$$

where $\mathrm{f}_{x}$ is a horizontal filter, $\mathrm{f}_{z}$ is a vertical filter, $\mathrm{J}$ is a Jacobian matrix, $\mathrm{J}^{T}$ is a Jacobian matrix transpose, $\mathrm{g}$ is a discrepancy vector of model data and observational data, $d$ is a disturbance vector model of observational data, $r$ is a vector containing logarithm and resistivity value of the model, and $\mu$ is a damping factor that serves to accelerate convergence [11].

Furthermore, the 2D resistivity cross-section model of each path is correlated to one 3D resistivity model. 2D and 3D resistivity models are marked with different contour colors, which shows the different resistivity values of the rocks con- 
TABLE I: Coordinates of research trajectories.

\begin{tabular}{|c|c|c|}
\hline Num & Line Name & Left and Right Track Coordinates \\
\hline 1. & Line-01 & $7^{\circ} 10^{\prime} 39.80^{\prime \prime} \mathrm{S} \& 108^{\circ} 47^{\prime} 29.50^{\prime \prime} \mathrm{E}-7^{\circ} 10^{\prime} 46.18^{\prime \prime} \mathrm{S} \& 108^{\circ} 47^{\prime} 28.06^{\prime \prime} \mathrm{E}$ \\
\hline 2. & Line-02 & $7^{\circ} 10^{\prime} 40.05^{\prime \prime} \mathrm{S} \& 108^{\circ} 47^{\prime} 30.22^{\prime \prime} \mathrm{E}-7^{\circ} 10^{\prime} 46.42^{\prime \prime} \mathrm{S} \& 108^{\circ} 47^{\prime} 28.77^{\prime \prime} \mathrm{E}$ \\
\hline 3. & Line-03 & $7^{\circ} 10^{\prime} 40.34 ” \mathrm{~S} \& 108^{\circ} 47^{\prime} 31.05^{\prime \prime} \mathrm{E}-7^{\circ} 10^{\prime} 46.70^{\prime \prime} \mathrm{S} \& 108^{\circ} 47^{\prime} 29.66^{\prime \prime} \mathrm{E}$ \\
\hline 4. & Line-04 & $7^{\circ} 10^{\prime} 40.63$ ” S \& $108^{\circ} 47^{\prime} 31.84^{\prime \prime} \mathrm{E}-7^{\circ} 10^{\prime} 46.98^{\prime \prime} \mathrm{S} \& 108^{\circ} 47^{\prime} 30.48^{\prime \prime} \mathrm{E}$ \\
\hline 5. & Line-05 & $7^{\circ} 10^{\prime} 40.90^{\prime \prime} \mathrm{S} \& 108^{\circ} 47^{\prime} 32.70^{\prime \prime} \mathrm{E}-7^{\circ} 10^{\prime} 47.28^{\prime \prime} \mathrm{S} \& 108^{\circ} 47^{\prime} 31.31^{\prime \prime} \mathrm{E}$ \\
\hline
\end{tabular}

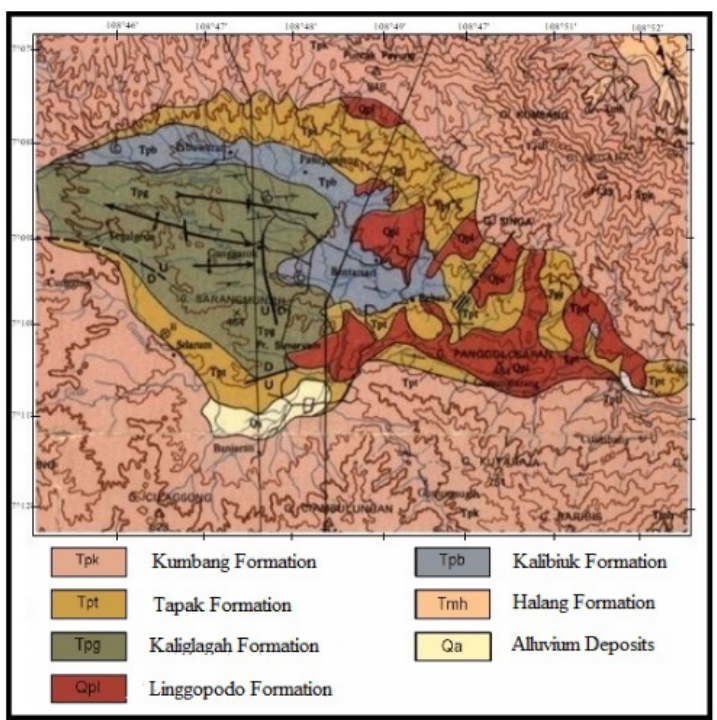

FIG. 5: Geological map of the Bentarsari Basin area of Salem District in the Majenang Geology Sheet [13].

tained therein. Interpretation is done to interpret the types of rocks and to get information about the description of subsurface rocks structures in the study area. Estimation of the subsurface rocks structures in the study area including coal deposits is carried out through the resistivity value approach of each rock based on the resistivity value standard table and the geological information of the study area. Interpretation of 2D and 3D-resistivity cross-section models results in 2D and 3Dlithological models that provide visual information about the distribution of coal in the area [12].

\section{RESULTS AND DISCUSSION}

Bentarsari Basin Area, Salem District, Brebes Regency has the potential of coal quarrying material, especially young coal. This can be seen from the geological information developing in the area. Geologically the Salem District area is composed of five rock formations, namely the Kumbang Formation, Tapak Formation, Kalibiuk Formation, Kaliglagah Formation, and Linggopodo Formation as shown in Fig. 5 [13]. The research area is included in the Kaliglagah Formation with the upper structure consisting of coarse sandstones and conglomerates; at the top, claystone and marlstone are reduced and
TABLE II: Results of interpretation of the combined lithology cross-sections of Line-01 through Line-05.

\begin{tabular}{ccccc}
\hline \hline Num & $\begin{array}{c}\text { Resistivity } \\
(\Omega \mathrm{m})\end{array}$ & $\begin{array}{c}\text { Rock } \\
\text { Type }\end{array}$ & $\begin{array}{c}\text { Depth Lithology } \\
(\mathrm{m})\end{array}$ & \\
\hline 1 & $<25.80$ & Clay & $0-28.7$ & $\square$ \\
2 & $23.50-98.40$ & Sandy clay & $0-28.7$ & $\square$ \\
3 & $86.10-219.00$ & Young Coal & $0-26.5$ & \\
\multicolumn{5}{c}{ (lignite) } \\
4 & $>200.00$ & Sandstone & $0-22.0$ & $\square$ \\
\hline \hline
\end{tabular}

even almost none. In the north-central part of the Bentarsari Basin, there are insertions of young coal with a thickness of 2-3 feet [13]. While the lower part is composed of black clay, green marl, andesite sandstones, and conglomerates. Generally, these sandstones are cross-coated with thin insertions of young coal, with thicknesses reaching $350 \mathrm{~m}$ [13].

The results of the inversion of the subsurface resistivity cross-section in 2D on the Line-01 line is shown in Fig. 6. The resistivity values obtained on the Line-01 line range from 6.33-169.00 $\Omega \mathrm{m}$. The maximum depth of the measurement obtained is $28.7 \mathrm{~m}$. The error value resulting from modeling using the least-squares inversion method is $8.3 \%$. Then 2D-resistivity cross-section after interpretation produces a lithology cross-section model as shown in Fig. 6. Lithology cross-section model on the Line-01 consists of four subsurface rock structure layers presented in Table II. The first layer has the smallest resistivity value of $6.33-25.80 \Omega \mathrm{m}$, and it is interpreted as clay. The clay is interspersed with a layer structure that has a higher resistivity value of $25.90-86.00$ $\Omega \mathrm{m}$ which is interpreted as sandy clay. The next layer that became the target of the study is young coal with a resistivity value of $86.10-200.00 \Omega \mathrm{m}$. While the highest resistivity value is $>200.00 \mathrm{~m}$ which is interpreted as sandstone.

In the same way, the results of inversion resistivity data modeling on Line-02 to Line-05 have produced some resistivity cross-sections, while the results of lithological interpretation have resulted in lithological cross-section of subsurface rocks, as shown in Fig. 7 and Fig. 8. Results of lithology interpretation for all complete resistivity cross-sections with their physical parameters are combined and shown in Table II.

Fig. 6 through Fig. 8 shows that the layer of young coal (lignite) appears dominant at a stretch of $100-180 \mathrm{~m}$ at a depth of $0-26.5 \mathrm{~m}$. The location of young coal on each 


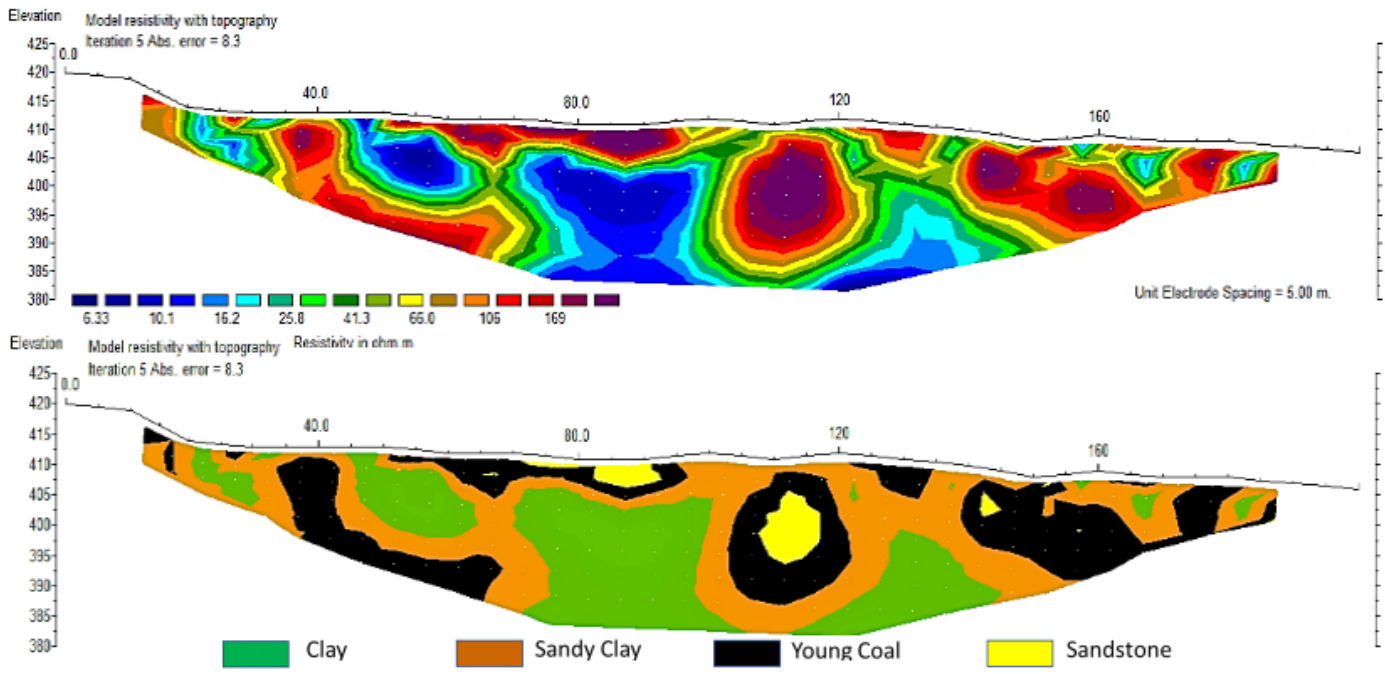

FIG. 6: Model of resistivity cross-section (top) and lithology cross-section (bottom) on the Line-01.

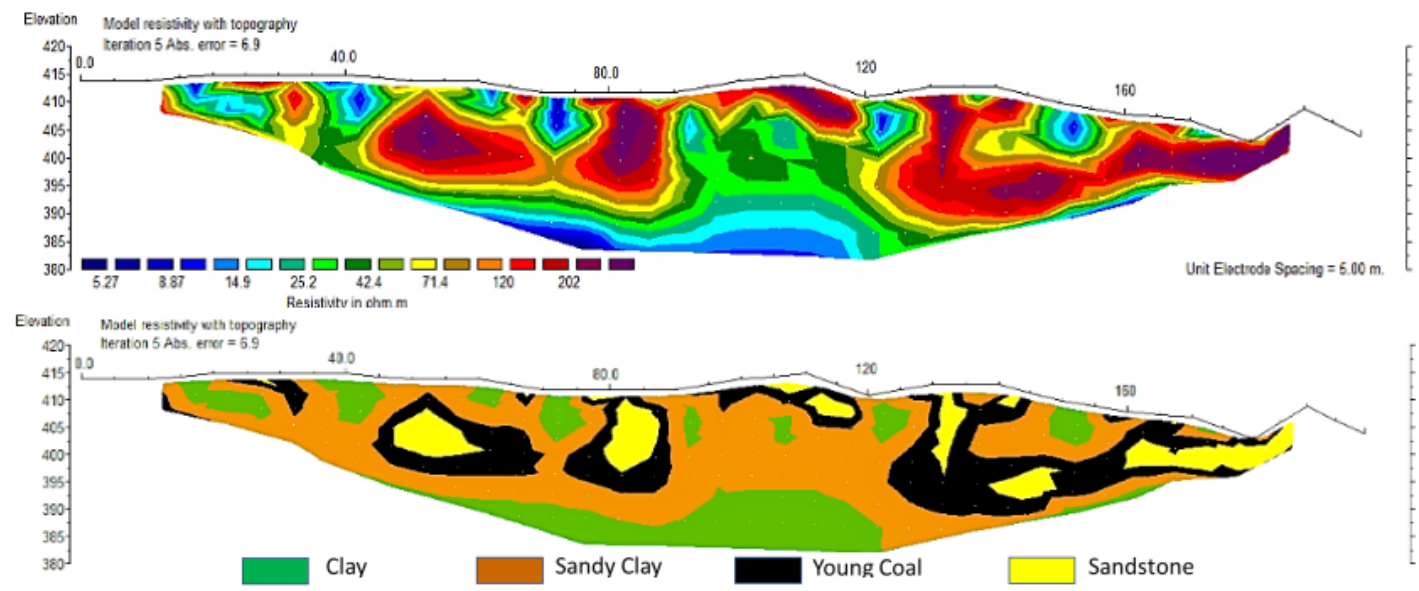

(a) Line-02

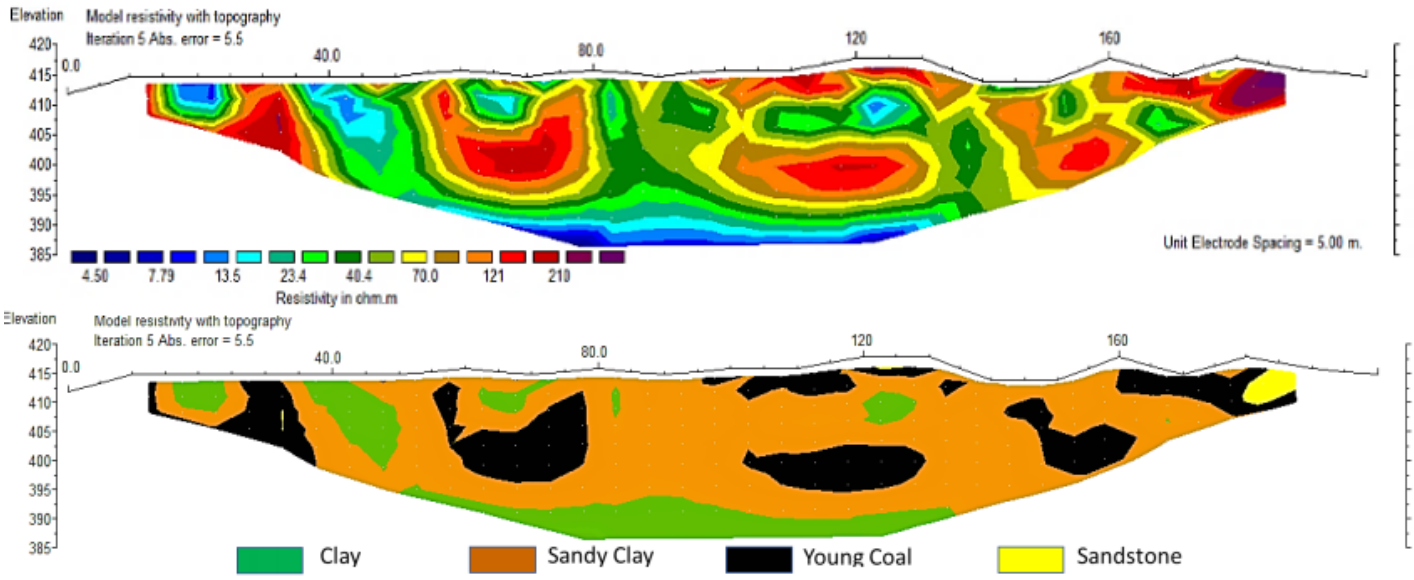

(b) Line-03

FIG. 7: Model of resistivity cross-section (top) and lithology cross-section (bottom) on (a) Line-02, (b). Line-03. 


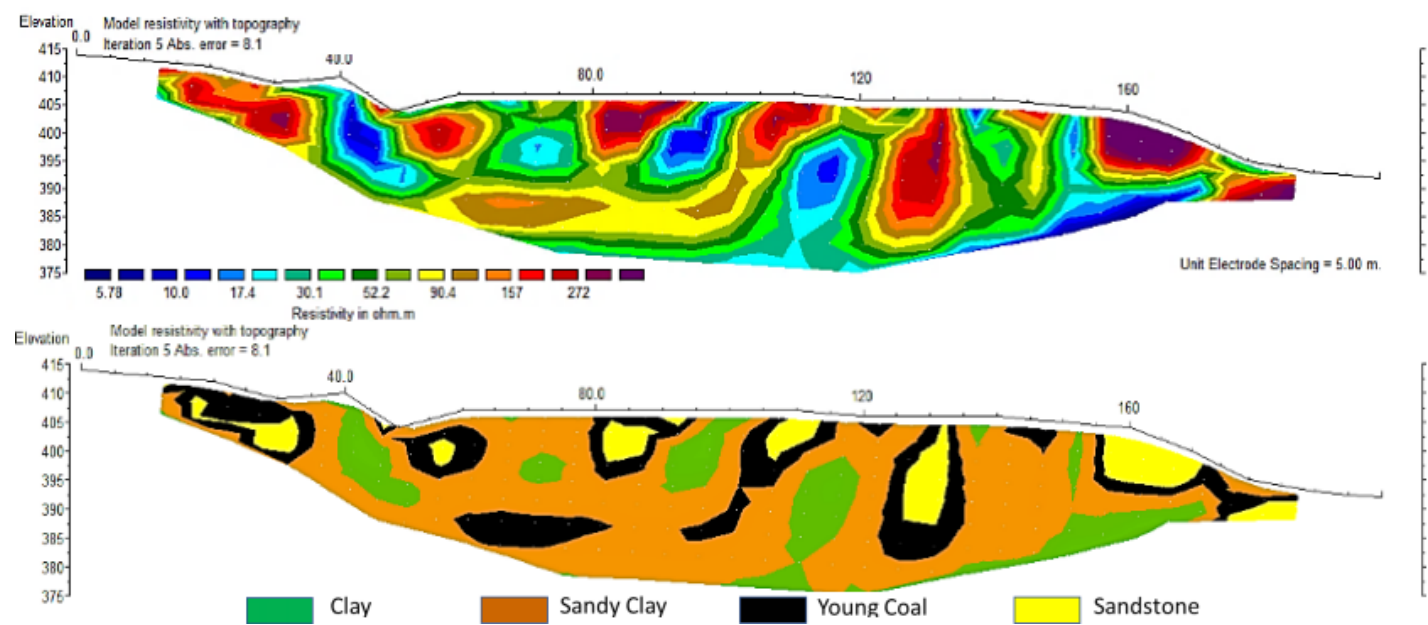

(a) Line-04

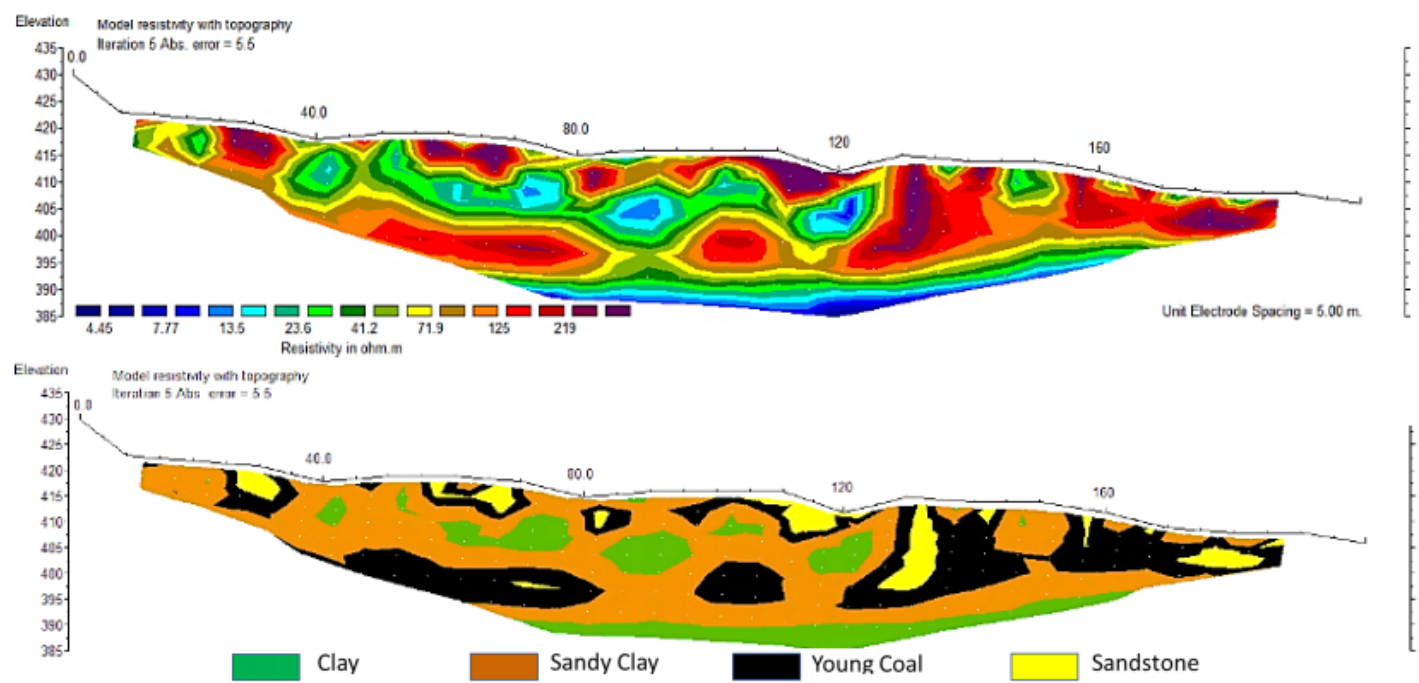

(b) Line-05

FIG. 8: Model of resistivity cross-section (top) and lithology cross-section (bottom) on (a) Line-04, (b). Line-05.

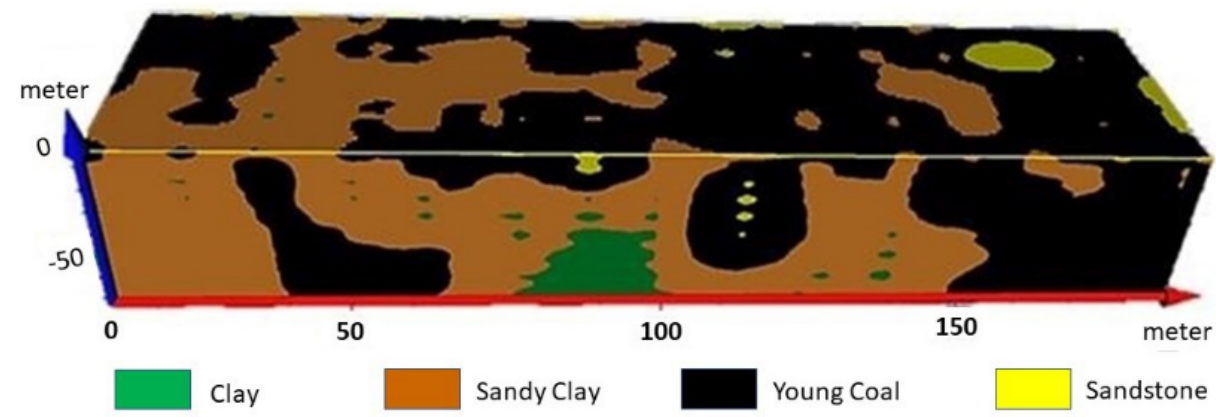

FIG. 9: 3D-lithological model depicting coal deposit models in the study area.

track is scattered and inserted in the structure of the sandy clay layer. The results of this interpretation are in accord with geological information, where sandstones are generally layered randomly or mixed with young coal seam structures in the Kaliglagah Formation [14]. The depth of the coal seam obtained in this study is distributed locally, so this is not seen in the results of previous studies using the satellite imagery gravity method and the magnetic method. Gravitational and magnetic methods are more global with broader research areas. Also, modeling and interpretation tend to be subjective 

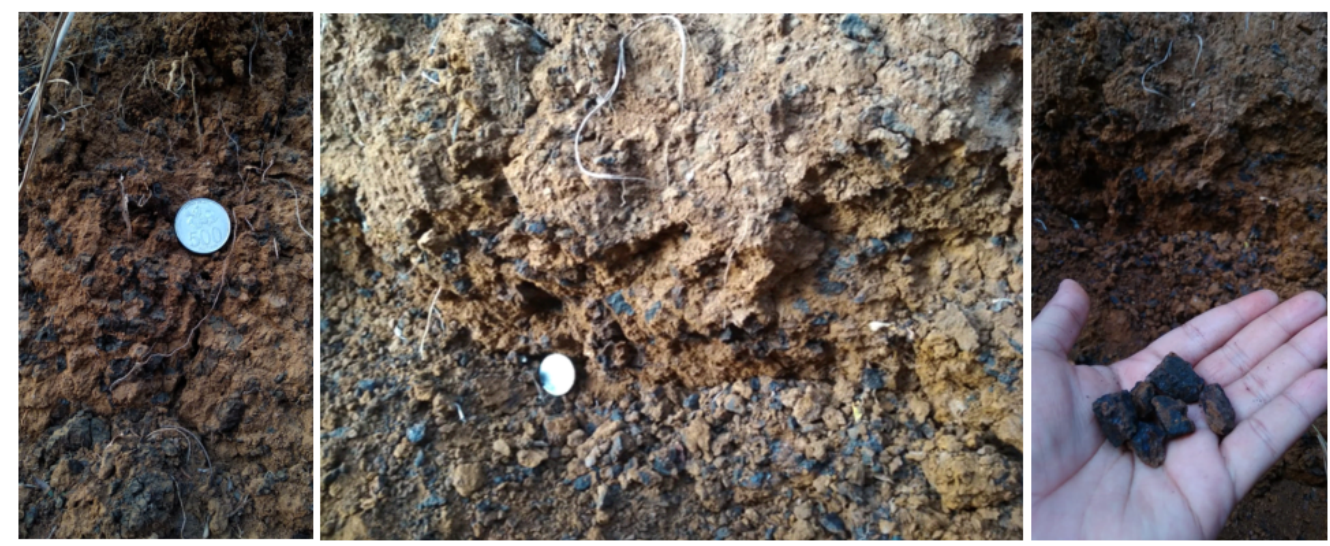

FIG. 10: Several outcrops of young coal that appear on the surface of the study area (source: personal photos).

because it uses 2D-forward modeling techniques [14,15]. Therefore, these two methods are less sensitive in describing the presence of young coal deposits that are inserted in the local sandy clay layer, but it is quite good in mapping the presence of coal deposits in the Kaliglagah Formation $[3,4]$.

The results of the correlation of the five lines of the lithology cross-section 2D model into the 3D lithology cross-section model can be seen in Fig. 9. Correlation is done because the distance between the lithology paths is relatively close and parallel. Besides, the intervals of resistivity values of subsurface rock types for each path are also relatively similar. The 3D lithology cross-section model shows that the structure of subsurface rock layers in the study area consists of four-layer structures namely clay, sandy loam, young coal, and sandstone with resistivity interval values as shown in Table II. In Fig. 9, the young coal seam is depicted with a black contour. The results of this correlation indicate that the coal layer is located at a depth of 0-26.5 meters with a resistivity value of $86.10-219.00 \Omega \mathrm{m}$.

Based on the results of modeling and interpretation, young coal deposits are evenly distributed in the study area but appear dominant in the southern part of the track. Besides, coal seams are generally found mostly on the surface. This is consistent with the number of coal outcrops on the surface in the area, as shown in Fig. 10. Geologically, the coal bed insert is located in the sandy clay layer structure, and sandstones are randomly layered or mixed with a thin layer of young coal. This will help the process of coal formation due to an increase in temperature and pressure [16]. Coal in the study area is still relatively young, but has a high economic value if it can be used as an alternative energy source; for example converted into briquettes, liquid coal, or synthetic oil to overcome current energy scarcity [17]. This research is still limited by a small area, therefore this research can be continued by expanding the surrounding area so that the results are complete.

\section{CONCLUSION}

Geophysical exploration using the resistivity geoelectric method with the Wenner configuration to model coal deposits in the Bentarsari Basin area, Salem District, Brebes Regency has been carried out. The results of the $2 \mathrm{D}$ resistivity crosssection interpretation produce a $2 \mathrm{D}$ lithology cross-section. Furthermore, each 2D lithology section is correlated, so a 3D lithology model is obtained which illustrates a young coal deposit model in the study area. The results of the interpretation are clay with resistivity values ranging from $4.45-25.80$ $\Omega \mathrm{m}$, sandy loam with resistivity values of $23.50-98.40 \Omega \mathrm{m}$, young coal with resistivity values ranging from $86.10-219.00$ $\Omega \mathrm{m}$, and sandstones with resistivity value of $>200.00 \Omega \mathrm{m}$. Distribution of young coal in the Bentarsari Basin area is spread evenly at a depth of $0-26.5 \mathrm{~m}$ with greater potential to the south of the track. The results of this study are in accord with geological information and are supported by the results of the analysis of gravity methods of satellite and magnetic images that show the presence of coal deposits in the Kaliglagah Formation.

\section{Acknowledgments}

The author would like to thank the Head of the Electronic, Instrumentation and Geophysics Laboratory, Faculty of Mathematics and Natural Sciences, Jenderal Soedirman University for the Naniura NRD-300 Geoelectric equipment and other supporting equipment provided. The author also expressed his gratitude to the entire data acquisition team, which has helped to do data acquisition in the field for several days in a compact and good manner. Besides, the authors also express their gratitude to those who helped in the processing, modeling, and interpretation of resistivity data until the research results were achieved. 
[1] S. Rumidi, "Batubara dan Gambut", Yogyakarta: Gadjah Mada University Press, 1995.

[2] W.H. Orem, and R.B. Finkelman, "Treatise on Geochemistry; Coal Formation and Geochemistry", vol. 7, pp. 191222, Elsevier Ltd., US Geological Survey, Reston, VA, USA.

[3] F.A. Kurniawan, dan Sehah, "Pemanfaatan Data Anomali Gravitasi Citra GEOSAT dan ERS-1 Satelitte untuk Memodelkan Struktur Geologi Bawah Permukaan Cekungan Bentarsari Kabupaten Brebes", Indonesian Journal of Apllied Physics (IJAP), vol. 02, no. 02, hal. 184-195, Oktober 2012.

[4] Sehah, S.A. Raharjo, dan A. Chandra, "Estimasi Kedalaman Batubara di Desa Banjaran Kecamatan Salem Kabupaten Brebes Berdasarkan Data Anomali Magnetik", Indonesian Journal of Applied Physics (IJAP), vol. 4, no. 2, hal. 171 182, Oktober 2014.

[5] L. Yue, "Application of Geophysical Technique in the Coal Mining", International Journal of Online and Biomedical Engineering, vol. 11, issue 7, pp. 11-13, 2015.

[6] A.A. Aning et al., "Electrical Resistivity as a Geophysical Mapping Tool; A Case Study Of The New Art Department, KnustGhana”, International Journal of Scientific and Research Publications, vol. 4, Issue 1, pp. 1-7, January 2014.

[7] I. Daruwati, "Penerapan Metode Geolistrik Resistivitas Konfigurasi Wenner untuk Mengetahui Dugaan Rembesan Polutan Sampah di Sekitar Tempat Pembuangan Akhir (TPA) Desa Tanjung Belit Kabupaten Rokan Hulu, Jurnal Edu Sains, vol. 2 no. 2, hal. 77-80, Juli 2019.

[8] W.M. Telford, R.E. Sheriff, L.P. Geldart, "Applied Geophysics", 2nd Ed., Cambridge: Cambridge University Press, 1990.

[9 ] D. Purwatiningtyas, Dasmo, A. Sjamsuri, "Application Of Resistivity Method Wenner Configuration For Determining Aquifer Position At Pasir Impun Area, Bandung, West Java", Proceeding of Ocean, Mechanical, and Aerospace, Science and Engineering, vol.2, October 21, 2015.
[10] Sehah, S.A. Raharjo, F. Destiani, "Interpretation of 2DSubsurface Resistivity Data in The Iron Ore Prospect Area of Eastern Binangun Coastal, Regency of Cilacap, Central Jawa”, Journal of Geoscience, Engineering, Environment, and Technology, vol. 03, no. 04, December 2018.

[11] E. Novia, Akmam, F. Mufit, "Identifikasi Jenis Batuan Menggunakan Metoda Geolistrik Tahanan Jeniskonfigurasi Wenner di Universitas Negeri Padang Kampus Air Tawar", Pillar of Physics, vol. 2, hal. 01-08, Oktober 2013.

[12] T.V.A. Lestari, dan Sehah, "Interpretasi Lapisan Pasir Besi Menggunakan Metode Resistivitas Konfigurasi Dipole-Dipole di Kawasan Desa Pagubugan Kecamatan Binangun Kabupaten Cilacap”, Bulletin of Scientific Contribution: GEOLOGY, vol. 18, no. 1, pp. 25-34, April 2020.

[13] Kastowo, "Peta Geologi Lembar Majenang, Jawa", Skala 1:100.000. Bandung: Pusat Penelitian dan Pengembangan Geologi, 1975.

[14] J.D. Phillips, "A Computer Program for the Geophysical Interpretation of Magnetic and Gravity Profiles Through Fourier Filtering, Source-Depth Analysis, and Forward Modeling", Virginia: U.S. Geological Survey, 2018.

[15] A. Bernard, O. Antony, A. Vincent, G. John, W. Ambusso, "2D-Forward Modeling of Ground Magnetic Data of HomaHills Geothermal Prospect Area, Kenya", International Journal of Science and Research (IJSR), vol. 3, issue 4, pp. 94-101, April 2014.

[16] S.F. Pamekas, Nurdrajat, R.M.G. Ghani, "Kerangka Sekuen Pengendapan Batubara Berdasarkan Analisis Nilai Sulfur dan Kadar Abu Daerah Bentarsari, Kecamatan Salem, Kabupaten Brebes, Provinsi Jawa Tengah", Padjadjaran Geosience Journal, vol. 3, no. 4, pp. 281-286, Agustus 2019.

[17] A. Vachlepi, dan D. Suwardin, "Penggunaan Biobriket sebagai Bahan Bakar Alternatif dalam Pengeringan Karet Alam", Warta Perkaretan, vol. 32, no. 2, hal. 65-73, Juli 2013. 